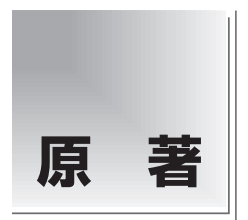

論文受付 2017 年 5 月 24 日

論文受理

2017 年 12 月 25 日

Code No. 251

\section{相対 artifact index によるノイズ特性に依存しない ストリークアーチファクト定量評価法の提案}

高田 賢 ${ }^{1}$ 市川勝弘 ${ }^{2}$ 坂野信也 ${ }^{1}$ 乙部克彦 ${ }^{1}$

\author{
${ }^{1}$ 大垣市民病院医療技術部診療検査科 \\ 2 金沢大学医薬保健学域保健学類
}

\section{緒 言}

Computed tomography (CT) 画像におけるアーチ ファクトとは「再構成画像中の CT 值と物体の真の減 弱係数の間の系統的不一致」と定義され ${ }^{1)}$, 呼吸や心 拍動などの動き, 散乱線, 線質硬化, フォトン不足, コーン角, 機器エラーなどさまざまな要因が原因とな り, 線状, 筋状, 風車状など多岐に渡る形状のアーチ ファクトが生じうる。アーチファクトは本来の被写体 が持つ信号の上に重なって描写され，CT 值や物体形 状を変化させることによって視認性 (病変検出能) や CT 值の信頼度 (性状診断能) を低下させる ${ }^{2 \sim 4)}$ 。これ によりアーチファクトが含まれない画像に比して画像 診断能が損なわれることとなり，アーチファクトがな い画像が理想的であることは明確である。どのような
条件で, どのようなアーチファクトが発生し, どの程 度の画像診断能が損なわれるかを評価することは，臨 床的価值が高い画像を提供することに直結し，そのた めにはアーチファクトを定量的に評価することが一助 となる。

$\mathrm{X}$ 線 CT 装置の性能評価に関する基準は 1979 年の $\lceil\mathrm{X}$ 線コンピュータ断層撮影装置の性能評価に関する 基準(第 1 次勧告) 」5) に始まり，時代とともに更新さ れ現在に至る。1991 年の「X 線 CT 装置性能評価に関 する基準(案)」而において，機械のアライメントによ るアーチファクトに関する評価法が記述され，直径 5 $\mathrm{mm}$ のアルミニウムピンを外形 $200 \mathrm{~mm}$ のファント 厶中央(周囲は水によって満たす)に挿入したものを患 者と同じ状態で寝台に乗せ，CT を撮影し(頭部撮影の

\title{
Suggestion of the Relative Artifact Index for Noise-independent Evaluation of the Streak Artifact
}

Ken Takada, ${ }^{1 *}$ Katsuhiro Ichikawa, ${ }^{2}$ Shinnya Banno, ${ }^{1}$ and Katsuhiko Otobe ${ }^{1}$

${ }^{1}$ Department of Medical Technology, Ogaki Municipal Hospital

${ }^{2}$ Institute of Medical, Pharmaceutical and Health Sciences, Kanazawa University

Received May 24, 2017; Revision accepted December 25, 2017

Code No. 251

\section{Summary}

The aim of this study was to inspect the usefulness of relative artifact index $\left(\mathrm{AI}_{\mathrm{r}}\right)$, which divided artifact index (AI) by standard deviation of the noise image for noise-independent evaluation of the streak artifact in computed tomography images. A water phantom without/with a cylindrical phantom filled with diluted contrast medium was scanned with different tube voltages $(100 / 120 / 140 \mathrm{kV})$ and radiation doses $(5 / 10 / 20 \mathrm{mGy})$, then images were reconstructed with different kernels (B10/30/50f). AI, location parameter in Gumbel method and $\mathrm{AI}_{\mathrm{r}}$ were measured in each condition and compared. The higher tube voltage or radiation dose or lower spatial resolution kernel, the lower quantitative values were presented by both $\mathrm{AI}$ and Gumbel method. $\mathrm{AI}_{\mathrm{r}}$ showed quantitative values independent of radiation dose and kernel, and substantial artifact amounts affected only by tube voltage. Our results showed $\mathrm{AI}_{\mathrm{r}}$ can evaluate quantitative artifact amount independent of image noise.

Key words: computed tomography (CT), streak artifact, artifact index, Gumbel distribution

*Proceeding author 
ルーチン条件), window level (WL)を水の值 (う0 HU), window width(WW)を 50, 100 および 400 に合 わせ写真またはフィルムに記録し，目視観察により評 価するとされる。しかし，この方法はノンヘリカルス キャンによる頭部撮影のみを対象としており，ヘリカ ルスキャンと多列化を達成し, より複雑で多様なアー チファクトを生じうる multi detector row CT (MDCT) 装置の評価法としては適切とは言い難い. 2017 年現在において最新の性能評価に関する報告で ある 2009 年の「 $\mathrm{MDCT}$ 装置の性能評価に関する基準 案の提案班報告」7)においては, アーチファクトにつ いて 3 項にわたる記載がなされ，その重要性が伺われ る。この中で, アーチファクトの定量評価法は, フラ クタル次元解析 ${ }^{8)}$, 複雑度評価 ${ }^{9}$ といった形状による 評価法とマスク法 ${ }^{9)}$, サブトラクション法 ${ }^{10)}$ といった CT 值による評価法が提示され, 撮影条件とアーチ ファクトの関係をある程度把握することは可能である としながらも, 定量評価に関しては確立されてはいな かった。

近年, $\mathrm{X}$ 線 CT 装置の大出力化に伴って低管電圧撮 影が行われるようになり，その有用性が多数報告され ている ${ }^{11 \sim 14)}$ 。低管電圧撮影は, 被ばく低減, ヨード造 影剤のコントラスト増強，またはそれを利用した造影 剤量低減などといった利点があるが，一方で骨や金属 などの高吸収体による X 線吸収が増大し, フォトン 不足や線質硬化によるストリークアーチファクトは増 強する ${ }^{15,16)}$. X 線 CT 装置によっては従来よりも細か な管電圧設定が可能であり, 管電圧設定はプロトコー ルを選択するうえで重要なファクターであると考えら れ，管電圧変化に対するストリークアーチファクトの 定量評価は重要であると考えられる。

ストリークアーチファクトの定量評価法としては, アーチファクトによる CT 值の標準偏差 (standard deviation: SD) の変化を測定する $\operatorname{artifact} \operatorname{index}(\mathrm{AI})^{17 \sim 21)}$, Gumbel 分布を用いた極值統計によるストリークアー チファクト定量評価法 (以下, Gumbel method; GM と する $)^{22 ~ 26)}$ が報告され, 研究において有効に利用され てきた，これらの評価法はいずれもアーチファクトに 起因すると思われる CT 值の変化 $(\mathrm{SD}$ および隣接ピ クセル間の最大変動)を指標として評価する手法であ り, 線量や kernel の変化といったノイズが変化する 場合においてはその定量值もノイズに依存して変化す る ${ }^{24)}$. しかし, この定量值の変化が単純にノイズ量に 比例した変化であるか，それとも他の要因にてアーチ ファクトが増減したためであるかの判断は AI および GMによる評価では判断ができない. よって本研究で
は,ノイズの影響を受けないストリークアーチファク 卜定量評価法として相対 AI を提案し, 管電圧変化に 対応したストリークアーチファクト評価としての有用 性を報告することを目的とする。また, ストリークアー チファクトの定量評価法としての AI と GM につい て，その定量值がどのような関係にあるか，同様の結 果を示すかを検討した報告はなく，併せて報告する．

\section{1. 方 法}

\section{1-1 Al による評価法の概要}

$\mathrm{AI}$ は式(1)のように定義され ${ }^{17 \sim 21)}$, 式中の $\sigma_{A}, \sigma_{B}$ は それぞれアーチファクトを含む画像 (以下, アーチ ファクト画像) 中における region of interest (ROI) 中 の $\mathrm{CT}$ 值の $\mathrm{SD}$, アーチファクトを含まない画像 (以 下，ノイズ画像) 中に扔ける ROI 中の CT 值の $\mathrm{SD}$ で ある。本手法において重要と考えられるのは“分散の 加法性”であり，これは確率変数がすべて独立な場合 は, 各変数の合計の分散の值は各変数の分散の和に等 しいという数学的に証明された理論である.すなわ ち, アーチファクト画像に扔ける分散 $\sigma_{A}^{2}$ はノイズ画 像の $\sigma_{B}^{2}$ とノイズの一種と見立てたアーチファクトの みの画像の $\sigma_{C}^{2}$ の和であると考えられ, 式 (2) の関倸 が成り立つ。 よってアーチファクト成分である AI $\left(=\sigma_{C}\right)$ は式(1)のとおり算出される.

$$
A I=\sqrt{\sigma_{A}^{2}-\sigma_{B}^{2}}
$$

$\sigma_{A}^{2}=\sigma_{B}^{2}+\sigma_{C}^{2}$

\section{1-2 GM による評価法の概要}

GM は Imai ら 22 26) により報告されたストリーク アーチファクト定量評価法であり, 2015 年, 2016 年に は本誌に扔いて GM によるストリークアーチファク トの等方性評価, 金属アーチファクト評価といった応 用論文が発表された ${ }^{27.28)}$. GM は, 画像ノイズが Gauss 分布をなすのに対し，ストリークアーチファク トによる CT 值変動が Gumbel 分布に従うことを用い た手法であり，原理上，画像ノイズによる影響を受け ることなくストリークアーチファクトの評価が可能で あるとされる ${ }^{28)}$. この評価法は, アーチファクト領域 に設定した ROI 内に線分を設定し，そのラインプロ ファイル中の最大変動量(画素間の CT 值差の最大值) を特徵量としている。極值統計の Gumbel 分布は(3) 式で表され， $F(x), \beta, \gamma$ はそれぞれ最大変動量 $x$ に対 する累積確率, 位置パラメータ, 尺度パラメータであ る. Gumbel plotの一次近似式の傾き $a$ および切片 $b$ から式(4)により位置パラメータ $\beta$ が算出され, これ 

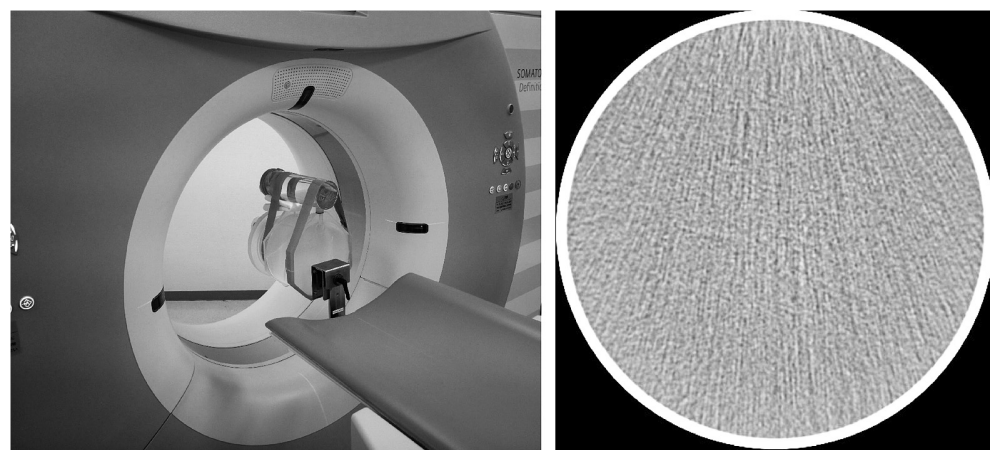

$a \mid b$

Fig. 1 Overview of the phantom.

(a) Entire photo, (b) Reconstruction image (WL: 0, WW: 100)

がアーチファクト量の指標として用いられる ${ }^{23 \sim 26)}$.

$F(x)=\exp \left[-\exp \left(-\frac{x-\beta}{\gamma}\right)\right]$

$\beta=-\frac{a}{b}$

\section{1-3 相対 Al による評価法の概要}

線量を低下させた場合や高解像特性を有する kernel で画像再構成を行った場合はノイズ画像とアーチ ファクト画像のいずれも CT 画像中のノイズが増加す る.このとき, AIによるアーチファクト定量評価に おいては，ノイズ画像の CT 值の分散 $\sigma^{2}{ }_{B}$ が増加する ことになるが, アーチファクト画像における CT 值の 分散 $\sigma^{2}{ }_{A}$ 中のノイズ成分も当然増加し, AI が高值と なった場合，それがアーチファクト $\left(\sigma^{2}{ }_{C}\right)$ の増加によ るものか，単に画像ノイズの変化割合に対して比例す るように増加したものかの判断ができない. また, AI は式(1)のとおりにアーチファクト画像とノイズ画像 における ROI 中の CT 值の SD の “比”ではなく“差” で定義されることから，画像ノイズが大きいほど $\sigma^{2}{ }_{A}$ と $\sigma_{B}^{2}$ の差が大きくなる，つまり定量值である $\mathrm{AI}$ が 大きくなることは明らかである．

Imaiらの報告において, GM における位置パラメー 夕は管電流時間積の平方根に反比例するとされ ${ }^{24,25)}$,

これはX 線 CTにおけるノイズと線量(管電流時間 積)の関係と同じである。このことは, 線量 (もしくは kernel) を変化させたとき, それらに伴うノイズ画像 のノイズ量の変化割合がrの場合, アーチファクト量 も $r$ とほぼ同じ割合で変化している可能性を示唆して いる。 この場合, AIにおいては, 式(1)中の $\sigma^{2}{ }_{A}$ と $\sigma_{B}^{2}$ はいずれも $r^{2}$ 倍となり, AI は $r$ 倍になると考えられ る.この「AIはノイズ画像の $\sigma_{B}$ の変化に比例する」 という仮定は, AIのノイズ画像の $\sigma_{B}$ に対する比をと り $\left(\sigma_{B}\right.$ で除し), 相対值とすることで, その仮定の真偽 が明らかになると考えられ，AIが kernel や線量によ
るノイズの変化に対して比例しない場合には，アーチ ファクトによる $\sigma_{C}$ がノイズ変化とは異なる変化を示 していることになり，アーチファクト自体の特性変化 がそこに示されるとわれわれは考えた。本研究におい て，AIをノイズ画像の $\sigma_{B}$ で除したものを相対 AI (relative artifact index; $\mathrm{AI}_{\mathrm{r}}$ ) と定義する(式(5)).

$A I_{r}=\frac{\sqrt{\sigma_{A}^{2}-\sigma_{B}^{2}}}{\sigma_{B}}$

\section{1-4 ファントムおよび画像取得}

本研究にはSIEMENS 社製 X 線 CT 装置である SOMATOM Definition AS+を使用し, 装置付属の直径 $200 \mathrm{~mm}$ の水ファントムをガントリ中央に配置して撮 影を行った。 また，ストリークアーチファクトを発生 させるために，ファントム上部 12 時方向に直径 70 $\mathrm{mm}$, 内部に $120 \mathrm{kV}$ において CT 值が約 $500 \mathrm{HU}$ とな るよう希釈した造影剤を封入した円柱ファントムを配 置した(Fig. 1a)。なお，本ファントム構成は，スト リークアーチファクトが肩部や骨盤部の骨，体内外の 金属等の高吸収物質から発生するという臨床的状況を 模擬するべく考案したものであるが，ファントム外の 上部に高吸収物体が存在することからストリークは ファントム内で主に下方向に向かって伸びる筋状㓌影 の集合となる(Fig. 1b). なお，人体を模擬したファン トム構成とは言い難いが，簡便な装置性能の評価のた めの方法を想定してこのようなモデルとした。

撮影条件は，管電圧：120 kV, volume CT dose index $\left(\mathrm{CTDI}_{\mathrm{vol}}\right)$ : $10 \mathrm{mGy}($ 装置表示值), rotation time: $0.5 \mathrm{~s}$, pitch : 0.7, 検出器配列 : $64 \times 0.6 \mathrm{~mm}$ を基本条件 とし, 水ファントムおよび水ファントム+円柱ファン 卜ムを撮影して画像を取得した(以降，それぞれノイ ズ画像，アーチファクト画像とする)，得られた投影 データより, 再構成スライス厚 : $5.0 \mathrm{~mm}$, 再構成スラ イス間隔 : $5.0 \mathrm{~mm}$, kernel : B30f(腹部標準関数), 
display field of view(DFOV) : $200 \mathrm{~mm}$ にて画像再構 成を行った。撮影は同一条件にて 5 回行い，1回の撮 影にて $\mathrm{z}$ 方向に 10 枚の画像を取得し, 計 50 枚の画像 を同一条件下における画像として取得した。

管電圧を変化させた場合，本ファントムモデルにお ける高吸収体によるX 線吸収の度合いの違いにより アーチファクト量が変化する可能性が考えられる。 ま た，線量および kernel を変化させた場合には，画像ノ イズ量抒よび周波数特性が変化し, アーチファクト定 量評価值へ影響を及ぼすことが想定される。このた め, 管電圧, 線量および kernel をパラメータとし, 基 本条件に対して管電圧を $100,140 \mathrm{kV} ， \mathrm{CTDI}_{\mathrm{vol}}$ を 5 , 20 mGy, kernel を B10f, B50f(数值が大きいほど高解 像特性を有する)に変化させ，画像取得を行った。 な お，変化させるパラメー夕は一つずつとし，それ以外 は基本条件とした(例; 管電圧変更時は線量および kernel は基本条件)。管電圧変更時には同一 $\mathrm{CTDI}_{\mathrm{vol}}$ $(10 \mathrm{mGy})$ となるよう管電流を調整した.

\section{1-5 ノイズ特性の評価}

本研究で提案する $\mathrm{AI}_{\mathrm{r}}$ の妥当性を証明するには, AI，GM が画像ノイズに依存し， $\mathrm{AI}_{\mathrm{r}}$ は画像ノイズに 依存しないことを示す必要がある。管電圧を変化させ た際，本研究で使用したX 線 CT 装置に扔いて，同一 線量であれば周波数特性を含め画像ノイズ特性が変化 しないことを確認するために，1-4 で取得したノイズ 画像における noise power spectrum (NPS)の測定を 行った。測定にはCT measure ver.0.96a ${ }^{29)}$ を用い, ノ イズ画像中央に配置した $256 \times 256$ pixel の ROI 中にお ける NPS 50 枚画像の加算画像より算出した.

\section{1-6 Al による評価}

1-4 にて取得したノイズ画像およびアーチファクト 画像の中央に $256 \times 256$ pixel の矩形 ROI を配置し, ROI 中の SD を計測し, 式(1)より AI を算出した。 な お式(1)中の $\sigma$ が $\mathrm{SD}$ に相当する。管電圧, $\mathrm{CTDI}_{\mathrm{vol}}$ お よび kernel を変化させたときの AIについて, 多重比 較 (Tukey 法)により平均值の差の検定を行った，SD の計測には Image $\mathrm{J}^{30)}$ ，統計解析には R(version 3.2.2) を使用した。

\section{1-7 GM による評価}

アーチファクト画像の中心 $(\mathrm{X}, \mathrm{Y}=256,256)$ より上 方向に 128 pixel の位置から下方向 127 pixel の位置ま で, X 方向長 256 pixel のラインプロファイルを 256 本取得した。 プロファイル上の最大変動量を抽出し,
Imai らと同様にミーンランク法にて累積確率 $F(x)$ の 推定を行い, 位置パラメータを算出した ${ }^{22)}$ 。管電圧, $\mathrm{CTDI}_{\mathrm{vol}}$ および kernel を変化させたときの位置パラ メータについて, 多重比較(Tukey 法)により平均值の 差の検定を行った。

\section{1-8 $\quad \mathrm{Al}_{\mathrm{r}}$ による評価}

1-6にて算出したAIをノイズ画像の SD で除する ことで $\mathrm{AI}_{\mathrm{r}}$ を算出した。管電圧, $\mathrm{CTDI}_{\mathrm{vol}}$ 抒よび kernel を変化させたときの $\mathrm{AI}_{\mathrm{r}}$ について, 多重比較 (Tukey 法)により平均值の差の検定を行った.

\section{1-9 Al と GM(位置パラメータ)の比較}

1-4 ストリークアーチファクト定量評価法として報 告されている $\mathrm{AI}$ と $\mathrm{GM}$ にて得られる定量值がどのよ うな関係にあるかを比較するため，1-6，1-7で得られ た AI および位置パラメー夕を基準条件における平均 值にて正規化し, 相対值にて比較を行った。管電圧変 更時では $100 \mathrm{kV}$ および $140 \mathrm{kV}, \mathrm{CTDI}_{\mathrm{vol}}$ 変更時では $5 \mathrm{mGy}$ および $20 \mathrm{mGy}$, kernel 変更時では B10f およ びB50fにおける AI と位置パラメータの相対值につ いて $\mathrm{t}$ 検定により検定を行った。

\section{2. 結 果}

\section{2-1 試料画像とノイズ特性}

Figure 2, 3 に各条件に打けるノイズ画像, アーチ ファクト画像の代表画像 (WL: 0, WW: 100, 表示画像 はファントム中心の 100×100 mm), Fig. 4 に管電圧, $\mathrm{CTDI}_{\mathrm{vol}}$ および kernel を変化させたときのノイズ画像 の NPS を示す，管電圧変化によるNPS の差はみられ ず, CTDI $\mathrm{Iol}_{\mathrm{vol}}$ 変化させた場合は低線量ほど高値とな るも周波数特性に変化を認めなかった. Kernel を変 化させた場合には 0.12 cycles/mm まではほぼ一致し, それ以上の空間周波数領域に打いて高解像度 kernel ほど高值となり, 周波数特性の変化を認めた。

\section{2-2 Al， GM および $\mathrm{Al}_{\mathrm{r}}$ による評価}

Figure 5 にAI, Fig. 6 に GM, Fig. 7 に AI 測定結果，またTable 1 にそれらをまとめたものを示 す。AIは, 管電圧を変化させた場合には $100 \mathrm{kV}, 120$ $\mathrm{kV}, 140 \mathrm{kV}$ の順に低值, $\mathrm{CTDI}_{\mathrm{vol}}$ を変化させた場合は $5 \mathrm{mGy}, 10 \mathrm{mGy}, 20 \mathrm{mGy}$ の順に低值, kernel を変化 させた場合は B10f, B30f, B50f の順に高值となり，い ずれのパラメー夕を変化させた場合においてもそれぞ れ群間に有意差を認めた，GMに打ける位置パラメー 夕も AI と同様の結果となり,いずれのパラメータを 

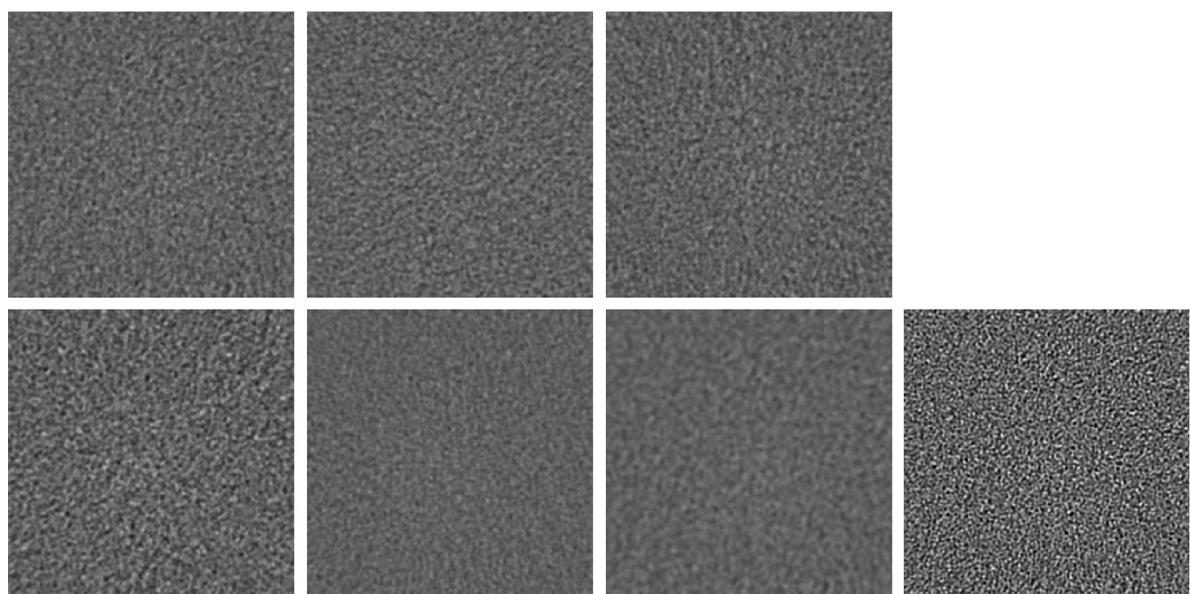

\begin{tabular}{l|l|l|l}
$a$ & $b$ & $c$ & \\
\hline$d$ & $e$ & $f$ & $g$
\end{tabular}

Fig. 2 Noise images in each scan and reconstruction condition.

(a) Standard condition, (b) $100 \mathrm{kV}$, (c) $140 \mathrm{kV}$, (d) $5 \mathrm{mGy}$, (e) $20 \mathrm{mGy}$, (f) B10f, (g) B50f (WL: 0, WW: 100)
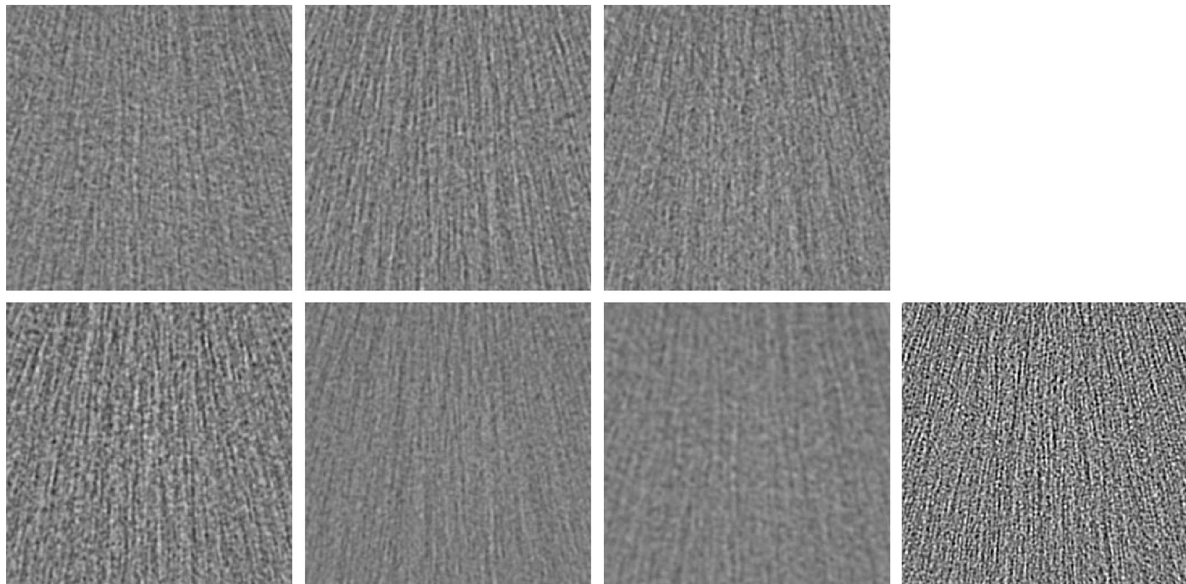

\begin{tabular}{l|l|l|l}
$a$ & $b$ & $c$ & \\
\hline$d$ & $e$ & $f$ & $g$
\end{tabular}

Fig. 3 Artifact images in each scan and reconstruction condition.

(a) Standard condition, (b) $100 \mathrm{kV}$, (c) $140 \mathrm{kV}$, (d) $5 \mathrm{mGy}$, (e) $20 \mathrm{mGy}$, (f) B10f, (g) B50f (WL: 0, WW: 100)

変化させた場合においてもそれぞれ群間に有意差を認 めた。

$\mathrm{AI}_{\mathrm{r}}$ は管電圧を変化させた場合には $100 \mathrm{kV}, 120$ $\mathrm{kV}, 140 \mathrm{kV}$ の順に低值となったが, CTDI $I_{\mathrm{vol}}$ を変化さ

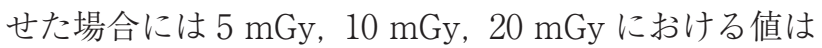
ほぼ等しく，有意差を認めなかった $(5-10 \mathrm{mGy}: p=$ 0.84, 10-20 mGy: $p=0.45, \quad 5-20$ mGy: $p=0.79)$. Kernel を変化させた場合も同様に，B10f，B30f，B50fに扔け る值はほほ等しくなり, 有意差を認めなかった(B1030f: $p=0.65$, B30-50f: $p=0.47$, B10-50f: $p=0.10$ ).

\section{2-3 Al と GM の比較}

Figure 8 扮よび Table 2 に AI と GM に打ける位置 パラメー夕を基準条件における平均値にて正規化して 比較した結果を示す。管電圧を変化させた場合には,
$100 \mathrm{kV}, 140 \mathrm{kV}$ における相対值に有意差を認めた. また，kernel を変化させた場合にもB10f，B50fにお ける相対值に有意差を認めた。CTDI 場合においては， $5 \mathrm{mGy} ， 20 \mathrm{mGy} に お け る$ 相対值に 有意差を認めなかった $(5 \mathrm{mGy}: p=0.90,20 \mathrm{mGy}: p=$ $0.79)$.

\section{3. 考 察}

ストリークアーチファクトについて, 管電圧, $\mathrm{CTDI}_{\mathrm{vol}}$ 抢よび kernel を変化させ，AI，GM および $\mathrm{AI}_{\mathrm{r}}$ により定量評価を行った，AIについては，高管電 圧ほど定量值は低下し, 先行研究 ${ }^{14)}$ と一致した結果が 得られた。また，GMについても，高線量ほど低值， 高解像度 kernel ほど高值となり, この結果も先行研 究24 26) と同様であった。 


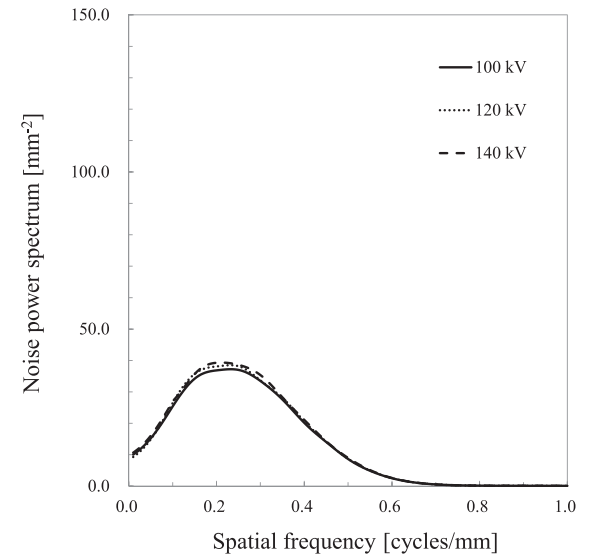

Fig. 4 Results of NPSs.

(a) Tube voltage, (b) CTDI $_{\text {vol, }}$ (c) Kernel
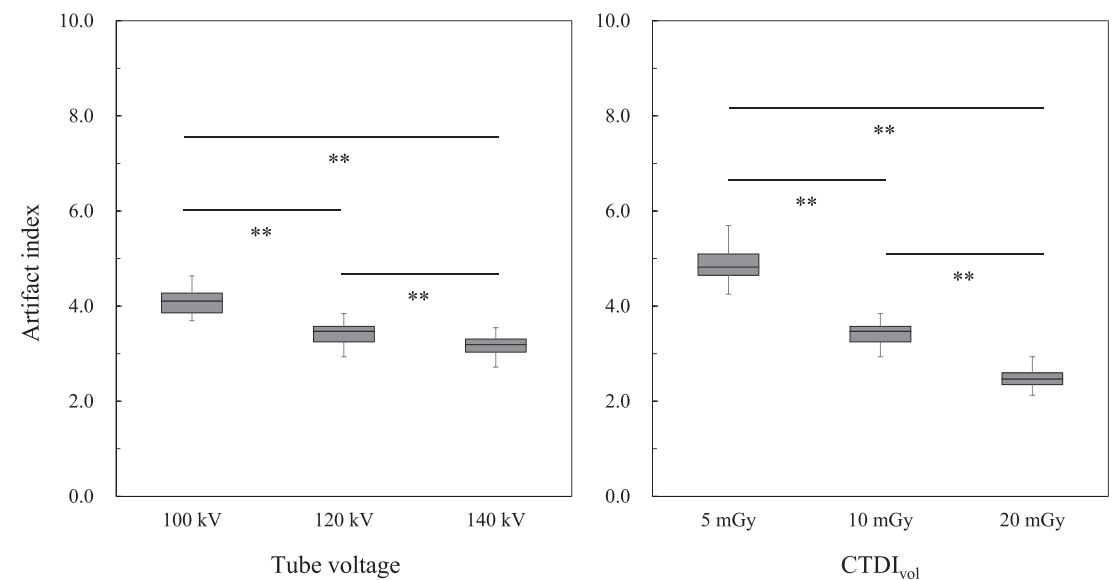

Fig. 5 Results of quantitative value measured by artifact index.

(a) Tube voltage, (b) CTDI $_{v o l}$, (c) Kernel
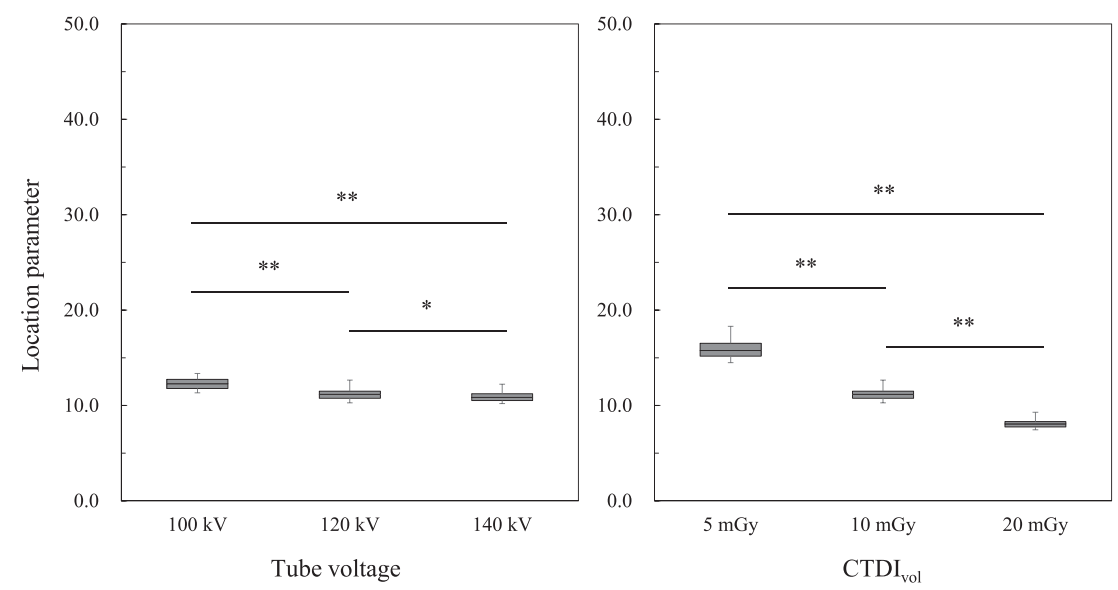

Fig. 6 Results of location parameter measured by Gumbel method.

(a) Tube voltage, (b) CTDI $_{\text {vol }}$, (c) Kernel

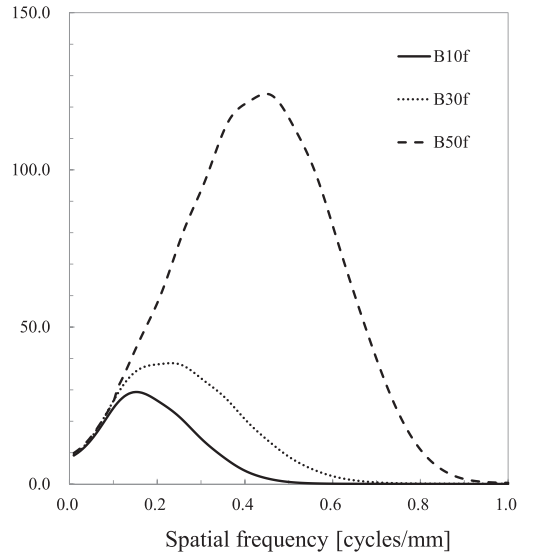

$\mathrm{a}|\mathrm{b}| \mathrm{c}$

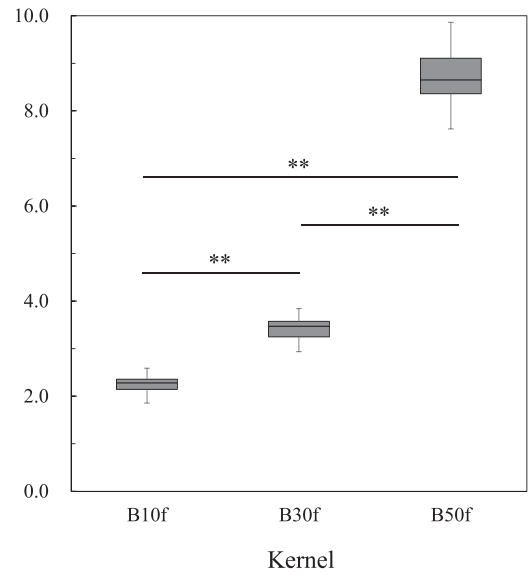

** $p<0.01$

$a|b| c$

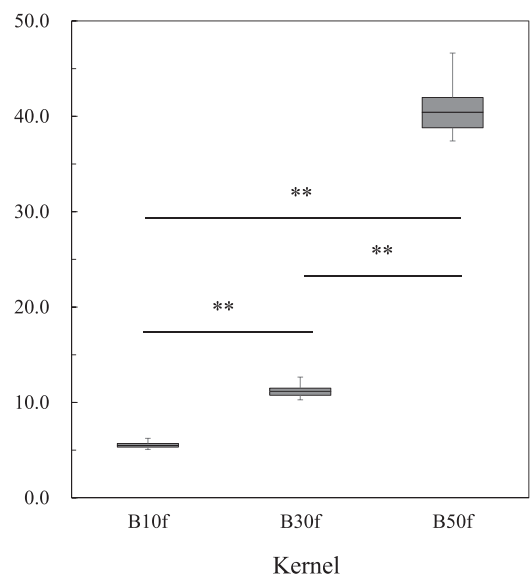

$* p<0.05$
$* * p<0.01$

$\mathrm{a}|\mathrm{b}| \mathrm{c}$ 


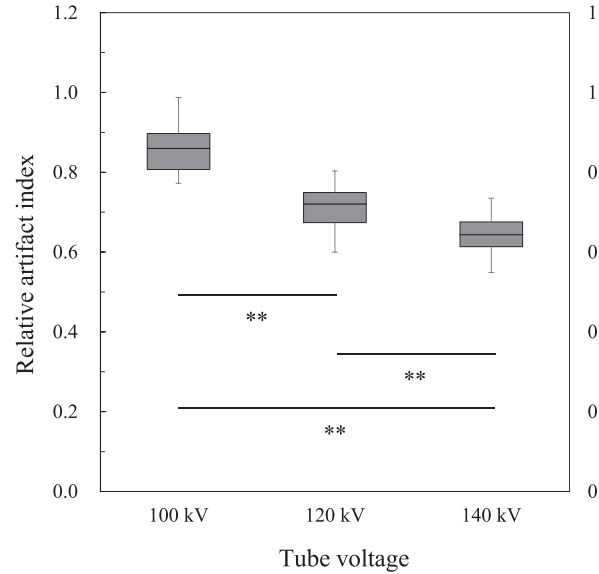

Tube voltage

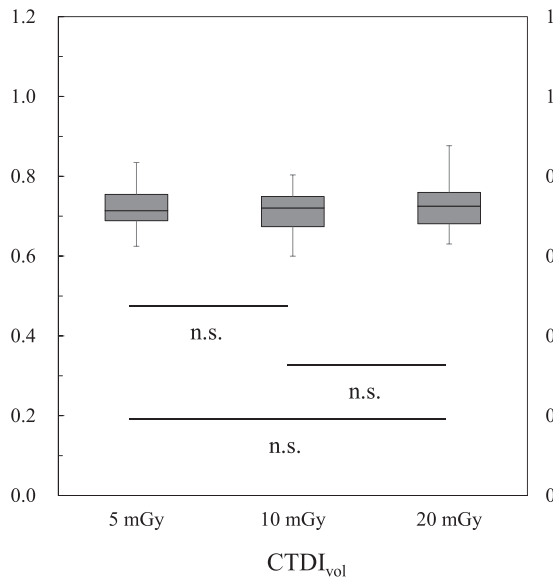

$\mathrm{CTDI}_{\mathrm{vol}}$

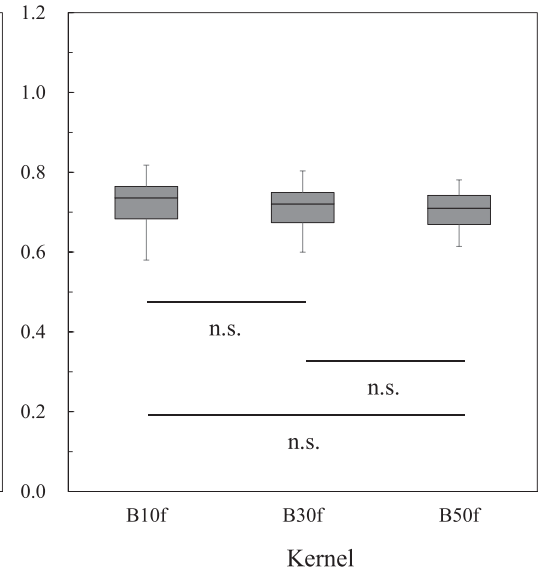

n.s.: not significant $* * p<0.01$

Fig. 7 Results of quantitative value measured by relative artifact index. (a) Tube voltage, (b) CTDI $_{\text {vol }}$, (c) Kernel

Table 1 Results of quantitative value measured by artifact index, Gumbel method and relative artifact index

\begin{tabular}{lccc}
\hline \hline \multicolumn{1}{c}{ Parameter } & Artifact index & Location parameter (GM) & Relative artifact index \\
\hline Tube voltage & & & \\
$100 \mathrm{kV}$ & $4.10 \pm 0.27$ & $12.26 \pm 0.62$ & $0.86 \pm 0.06$ \\
$120 \mathrm{kV}$ & $3.43 \pm 0.23$ & $11.16 \pm 0.55$ & $0.72 \pm 0.05$ \\
$140 \mathrm{kV}$ & $3.17 \pm 0.21$ & $10.91 \pm 0.47$ & $0.64 \pm 0.05$ \\
$P$-value $(100-120 \mathrm{kV})$ & $<0.01$ & $<0.01$ & $<0.01$ \\
$P$-value $(120-140 \mathrm{kV})$ & $<0.01$ & $<0.01$ & $<0.01$ \\
$P$-value $(100-140 \mathrm{kV})$ & $<0.01$ & 0.04 & $<0.01$ \\
CTDI & & & \\
5 mGol & $4.87 \pm 0.34$ & $15.86 \pm 0.89$ & $0.72 \pm 0.05$ \\
10 mGy & $3.43 \pm 0.23$ & $11.16 \pm 0.55$ & $0.72 \pm 0.05$ \\
20 mGy & $2.49 \pm 0.18$ & $8.07 \pm 0.37$ & $0.73 \pm 0.06$ \\
$P$-value $(5-10 \mathrm{mGy})$ & $<0.01$ & $<0.01$ & 0.84 \\
$P$-value $(10-20 \mathrm{mGy})$ & $<0.01$ & $<0.01$ & 0.45 \\
$P$-value $(5-20 \mathrm{mGy})$ & $<0.01$ & $<0.01$ & 0.79 \\
Kernel & & & \\
B10f & $2.26 \pm 0.16$ & $5.52 \pm 0.27$ & $0.72 \pm 0.06$ \\
B30f & $3.43 \pm 0.23$ & $11.16 \pm 0.55$ & $0.72 \pm 0.05$ \\
B50f & $8.69 \pm 0.57$ & $40.48 \pm 2.17$ & $0.70 \pm 0.05$ \\
$P$-value (B10-30f) & $<0.01$ & $<0.01$ & 0.65 \\
$P$-value (B30-50f) & $<0.01$ & $<0.01$ & 0.47 \\
$P$-value (B10-50f) & $<0.01$ & $<0.01$ & 0.10 \\
\hline
\end{tabular}

AIr による評価では, 線量を変化させた場合にはそ の定量值に条件による差を認めなかった。この結果か ら，AIはノイズ量と比例する,つまりストリークアー チファクト量のノイズ量に対する割合は線量に依らず 一定である(本研究においてはノイズ量の約 0.7 倍)こ とが示された. Kernel を変化させた場合には, アー チファクト画像においてもそのノイズ特性が変化する が,アーチファクト自体も kernel の特性を反映した
像として再構成されるため AI，GM による評価値は Fig. 5c, Fig. 6c に示す通りに高解像度な kernel ほど 増加した。ここで, 同一の投影データから異なる kernel で再構成された画像間の解像特性およびノイ ズ特性の差はフィル夕関数による空間周波数処理にほ ぼ等しい ${ }^{31)}$ と考えられるため, アーチファクト画像に 空間周波数処理を行うことで，同一の空間周波数特性 を有する画像とすることが可能であると考えられる. 

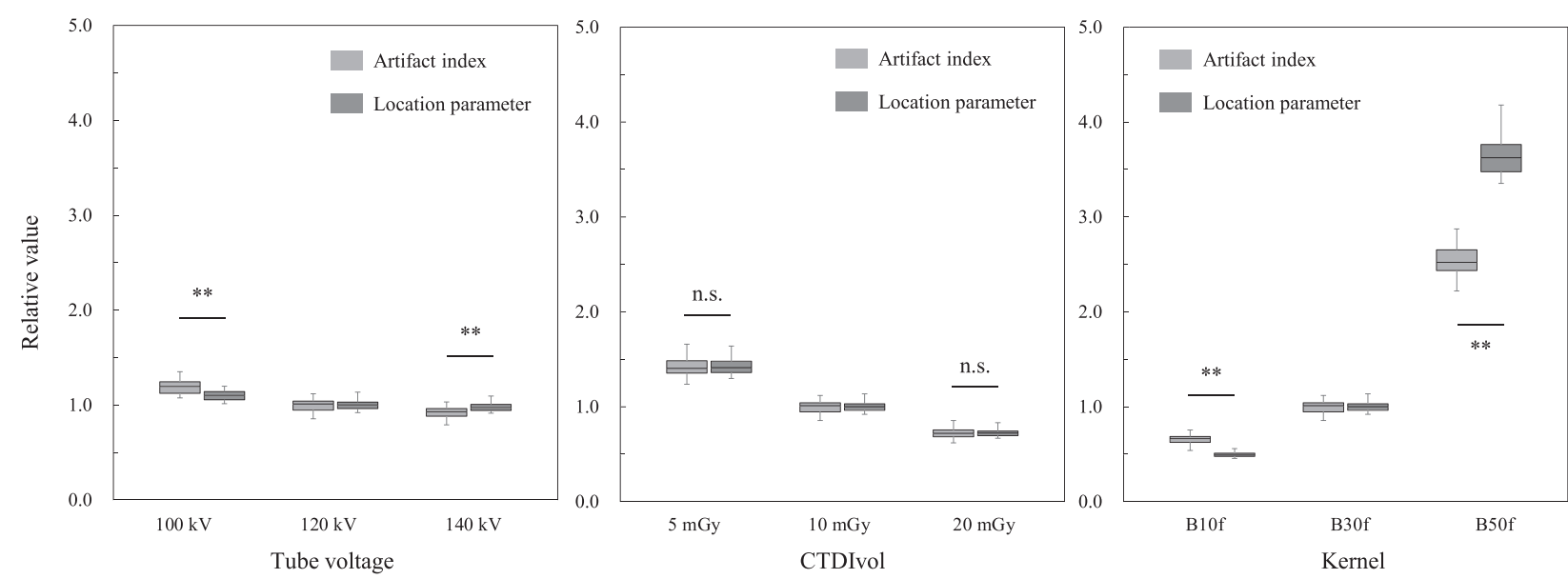

Fig. 8 Results of relative value normalized standard condition. (a) Tube voltage, (b) CTDI $_{\text {vol }}$, (c) Kernel

n.s.: not significant $* * p<0.01$

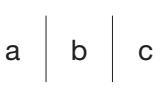

Table 2 Comparison between relative value of artifact index and location parameter measured by Gumbel method that normalized by quantitative value in standard condition

\begin{tabular}{cccc}
\hline \hline Parameter & Artifact index & Location parameter & $P$-value \\
\hline $\begin{array}{c}\text { Tube voltage } \\
100 \mathrm{kV}\end{array}$ & $1.20 \pm 0.08$ & $1.10 \pm 0.06$ & $<0.01$ \\
$120 \mathrm{kV}$ & $0.92 \pm 0.06$ & $0.98 \pm 0.04$ & $<0.01$ \\
$140 \mathrm{kV}$ & $1.42 \pm 0.10$ & $1.42 \pm 0.08$ & 0.90 \\
CTDI $_{\mathrm{vol}}$ & $0.73 \pm 0.05$ & $0.72 \pm 0.03$ & 0.79 \\
$5 \mathrm{mGy}$ & & & \\
$10 \mathrm{mGy}$ & $0.66 \pm 0.05$ & $0.49 \pm 0.02$ & $<0.01$ \\
$20 \mathrm{mGy}$ & & & \\
Kernel & & & \\
B10f & & & \\
B30f & $2.53 \pm 0.17$ & $3.63 \pm 0.19$ & $<0.01$ \\
B50f & & &
\end{tabular}

B10fのノイズ画像の NPS の平方根を B30f, B50fのノ イズ画像の NPS の平方根で除して算出した frequency processing factor $(\mathrm{FP})$ をアーチファクト画像 に対して空間周波数処理を行い，等しい空間周波数特 性を有する画像としたものを Fig. 9 に示す(市川らの 報告 ${ }^{31)}$ においては modulation transfer functionの比 をFPとしている). 空間周波数処理後の画像 (Fig. 9d, e) はいずれも視覚的にオリジナルのB10fのアー チファクト画像 (Fig. 9a)に類似し, B10f オリジナル, B30f およびB50fの空間周波数処理後のアーチファク 卜画像の SD はそれぞれ $3.73 \pm 0.12 ， 3.76 \pm 0.12 ， 3.75 \pm$ 0.12 とほほ等しい值となった。このことから, kernel を 変化させた場合のアーチファクト量の変化は, kernel の特性を反映したものであり， $\mathrm{AI}_{\mathrm{r}}$ においてはその影 響を除外した評価が可能であることが示された。管電
圧に関しては，高管電圧ほど $\mathrm{AI}_{\mathrm{r}}$ が低值となる変化が みられた。これは $\sigma_{B}$ の変化に $\sigma_{C}$ が従わず, 低管電圧ほ ど高吸収体による X 線吸収が大きくフォトン不足と なり，ストリークアーチファクトが増大するという管 電圧依存性があることが示されたものと考えられる。

AI と GM の比較において, 線量の変化による AI と GM の定量值 (相対值)には差を認めなかった。この結 果より, 本研究で検討した線量の範囲内においては, 画像の周波数特性が変化しない場合においては, 画像 ノイズ量に差がある場合においても AI と GM はいず れも同等の感度を有することが示された. Kernel を 変化させた場合には，GM は AI に比し大きな差を認 めたが，これは AI が標準偏差を用いているのに対し， GM は最大変動を指標としているため, kernel の変化 に伴う CT 值変化をより鋭敏に反映した結果と考えら 

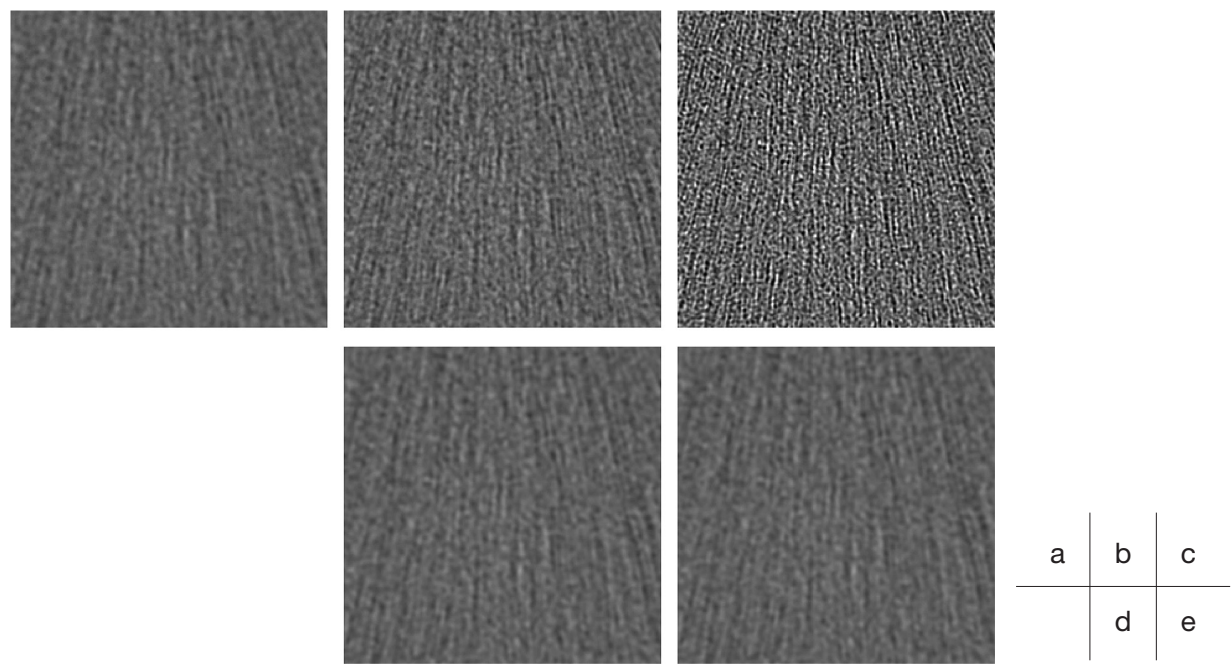

Fig. 9 Pre- and post-frequency processing artifact images.

(a) B10f, (b) B30f, (c) B50f, (d) B10f post processing, (e) B50f post processing

(WL: 0, WW: 100)
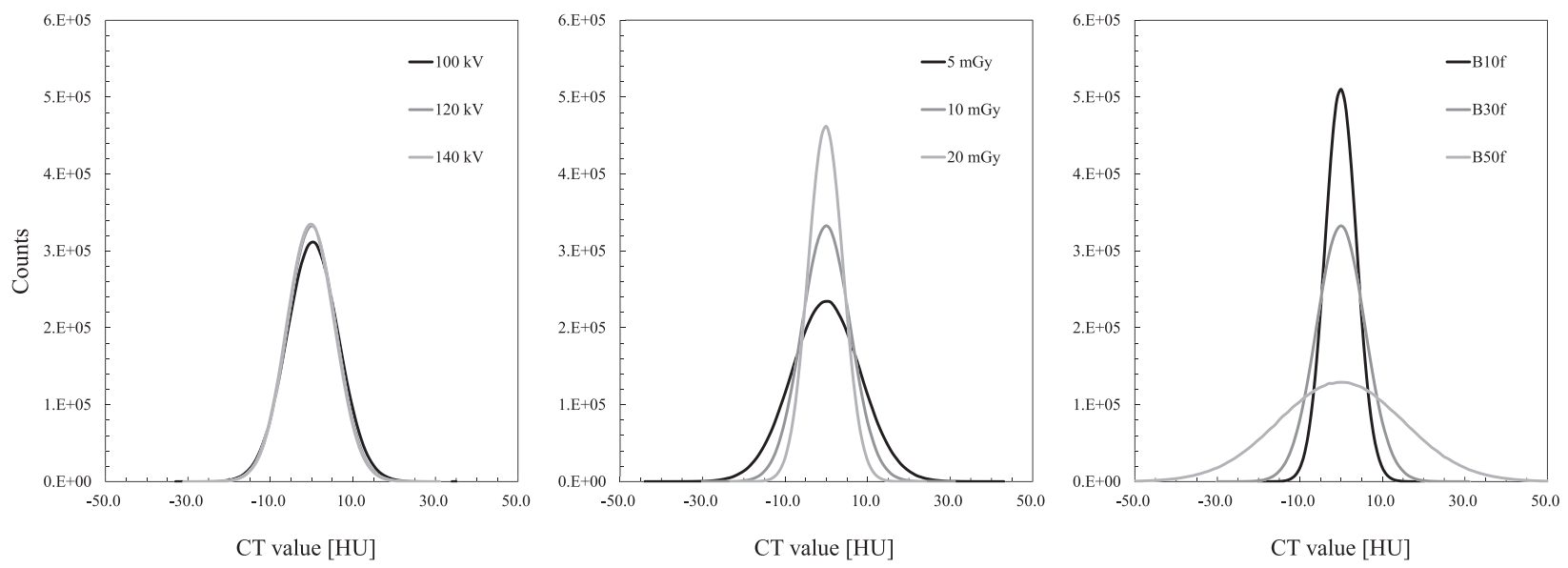

Fig. 10 Histogram of artifact images. (a) Tube voltage, (b) CTDI $_{\text {vol }}$, (c) Kernel

れる，管電圧変化に対しては，AI が GMに比しより 高い感度で差を認めたが，線量を変化させたときの結 果より周波数特性の変化がない場合は AI と GM の感 度は同等であると考えられるため，この差は管電圧変 化によるアーチファクトの差を反映した結果であると 考えられる. Figure 10 に各条件におけるアーチファ クト画像のヒストグラムを示す。線量および kernel の変化に対して，管電圧を変化させた場合における $\mathrm{CT}$ 值分布の変化は小さく，いずれの管電圧において もほぼ一定の範囲内での CT 值変動であるため, SD を指標としている AI が GM に比し高い感度を有した と推察する。本研究により得られた AI と GM の定量 值間の関係については過去に報告はなく, 周波数特性 が変化しない場合には感度は同等，周波数特性が変化
する場合には GM の感度が高いという知見は新たな ものであると思われる。

アーチファクト定量評価の問題点でもあるが，アー チファクトの真值を知ることができないためいずれの 評価法の結果が真值に近いかも不明であり，その優劣 について論じることは本研究結果からはできない. GM はアーチファクト画像のみで評価が可能であると いう利点があり，臨床画像を用いた評価に有用であ る。しかし，この手法は計算手法が難解，煩雑であり $\mathrm{X}$ 線 CT 装置の標準の機能 (SD 計測と CT 值計測) で は計測不可能であることが欠点として挙げられる. AI はその概念の理解し易さ，計算の簡便さが利点と 思われ，欠点としてはノイズ画像とアーチファクト画 像をそれぞれ必要とすることが考えられる。本研究結 
果から, AI, GM はいずれも管電圧, CTDI $\mathrm{V}_{\mathrm{vol}}$, kernel を変化させた際の定量值は同様の傾向を示したため, 同一の手法で各種条件におけるアーチファクトについ ての比較を行う場合にはいずれの手法も有用であると 思われた。ここに $\mathrm{AI}_{\mathrm{r}}$ を併用することで，ノイズ変化 以外の要因によるアーチファクトの増減について知る ことが可能となり，より詳細な評価が可能になると考 えられた。

AI, GM, AI $\mathrm{I}_{\mathrm{r}}$ はいずれもストリークアーチファクト の周波数成分の評価はなされていない.NPSによる ノイズ評価のような周波数成分の評価法が確立されれ ば, 例として直径 $x \mathrm{~mm}$, CT 值差 $y \mathrm{HU}$ の物体に対す る影響などの評価も可能となると考えられるが，これ については変わらず課題のままである。また，本研究
ではヘリカルスキャンにおける特定方向からのスト リークアーチファクトのみを対象としていること, ファントム検証のみであり臨床画像による評価ではな いことは limitation である。

\section{4. 結 語}

本研究結果より, 本ファントムモデルに扔けるスト リークアーチファクト量はノイズ量に比例することが 明らかとなり， $\mathrm{AI}_{\mathrm{r}}$ による評価によってノイズ特性に 依存しないストリークアーチファクト評価が可能で あった。 また, 周波数特性が異なる画像間のストリー クアーチファクトの比較においては AI に比し GM の 感度が高く, 周波数特性が変化しない場合には AI と GM の感度は同等であることが示された。

\section{参考文献}

1) Barrett JF, Keat N. Artifacts in CT: recognition and avoidance. Radiographics 2004; 24(6): 1679-1691.

2) Brink M, de Lange F, Oostveen LJ, et al. Arm raising at exposure-controlled multidetector trauma CT of thoracoabdominal region: higher image quality, lower radiation dose. Radiology 2008; 249(2): 661-670.

3) Kahn J, Grupp U, Maurer M. How does arm positioning of polytraumatized patients in the initial computed tomography (CT) affect image quality and diagnostic accuracy? Eur J Radiol 2014; 83(1): e67-71.

4) Karlo C, Gnannt R, Frauenfelder T, et al. Whole-body CT in polytrauma patients: effect of arm positioning on thoracic and abdominal image quality. Emerg Radiol 2011; 18(4): 285-293.

5）竹中栄一, 飯沼 武, 遠藤真広, 他. X線コンピュー夕断 層撮影装置の性能評価に関する基準 (第 1 次勧告). 日本 医師会雑誌 1979; 82: 1175-1185.

6）速水昭雄, 伊藤博美, 岡本日出夫, 他. X 線 CT 装置性能 評価に関する基準(案)。日放技学誌 1991; 47(1): 56-63.

7）片倉俊彦, 森 一生, 辻岡勝美, 他. MDCT 装置の性能評 価に関する基準案の提案班報告. 日放技学誌 2009; 65(4): 491-502.

8）原 孝則, 加藤秀記, 津坂昌利. フラクタル次元解析を用 いた 4 Row Multislice Spiral CT における Z 方向のデータ 乗換えの複雑性評価. 日放技学誌 2003; 59(4): 494-499.

9）村上克彦. シンポジウム I: CT 装置の新しい性能評価 1. アーチファクトヘリカルアーチファクト定量化の試 み. Innervision 2005; 20(12): 5-9.

10）西丸英治, 宇都宮律子, 西江亨文, 他. サブトラクション 処理を用いたへリカルアーチファクトの新しい評価法. 日放技学誌 2005; 61(7): 1021-1026.

11) Funama $Y$, Awai $K$, Nakayama $Y$, et al. Radiation dose reduction without degradation of low-contrast detectability at abdominal multisection CT with a low-tube voltage technique: phantom study. Radiology 2005; 237(3): 905-910.

12) Nakayama $Y$, Awai K, Funama $Y$, et al. Abdominal CT with low tube voltage: preliminary observations about radiation dose, contrast enhancement, image quality, and noise. Radiology 2005; 237(3): 945-951.

13) Noda $Y$, Kanematsu M, Goshima $S$, et al. Reducing iodine load in hepatic CT for patients with chronic liver disease with a combination of low-tube-voltage and adaptive statistical iterative reconstruction. Eur J Radiol 2015; 84(1): 11-18.

14) Takahashi H, Okada M, Hyodo T, et al. Can low-dose CT with iterative reconstruction reduce both the radiation dose and the amount of iodine contrast medium in a dynamic CT study of the liver? Eur J Radiol 2014; 83(4): 684-691.

15) Seyal AR, Arslanoglu A, Abboud SF, et al. CT of the abdomen with reduced tube voltage in adults: a practical approach. Radiographics 2015; 35(7): 1922-1939.

16) Park JE, Choi YH, Cheon JE, et al. Image quality and radiation dose of brain computed tomography in children: effects of decreasing tube voltage from $120 \mathrm{kVp}$ to $80 \mathrm{kVp}$. Pediatr Radiol 2017; 47(6): 710-717.

17) Lin XZ, Miao F, Li JY, et al. High-definition CT Gemstone spectral imaging of the brain: initial results of selecting optimal monochromatic image for beam-hardening artifacts and image noise reduction. J Comput Assist Tomogr 2011; 35(2): 294-297.

18) Dong Y, Shi AJ, Wu JL, et al. Metal artifact reduction using virtual monochromatic images for patients with pedicle screws implants on CT. Eur Spine J 2016; 25(6): 1754-1763.

19）坪井邦仁, 福永正明, 山本浩之. Computed tomographyに おける calibration field of view や display field of view が及 ぼす金属アーチファクト低減効果の影響. 日放技学誌 2016; 72(12): 1237-1244.

20) Hu Y, Pan S, Zhao X, et al. Value and clinical application of orthopedic metal artifact reduction algorithm in CT scans after orthopedic metal implantation. Korean J Radiol 2017; 18(3): 526-535.

21) Kuya K, Shinohara Y, Kato A, et al. Reduction of metal artifacts due to dental hardware in computed tomography angiography: assessment of the utility of model-based iterative reconstruction. Neuroradiology 2017; 59(3): 231-235.

22) Imai $K$, Ikeda $M$, Wada $S$, et al. Analysis of streak artefacts on CT images using statistics of extremes. Br J Radiol 2007; 80 (959): 911-918.

23) Imai K, Ikeda M, Enchi $Y$, et al. Quantitative assessment of image noise and streak artifact on CT image: comparison of zaxis automatic tube current modulation technique with fixed 
tube current technique. Comput Med Imaging Graph 2009; 33 (5): 353-358.

24) Imai K, Ikeda M, Enchi Y, et al. Statistical characteristics of streak artifacts on CT images: relationship between streak artifacts and mA s values. Med Phys 2009; 36(2): 492-499.

25) Imai $K$, Ikeda $M$, Enchi $Y$, et al. A detection method for streak artifacts and radiological noise in a non-uniform region in a CT image. Phys Med 2010; 26(3): 157-165.

26) Imai $K$, Ikeda $M$, Kawaura $C$, et al. Dose reduction and image quality in $\mathrm{CT}$ angiography for cerebral aneurysm with various tube potentials and current settings. Br J Radiol 2012; 85(1017): e673-681.

27）中根 淳, 小林芳春, 塩澤 努. ストリークアーチファク
卜に対する極值統計解析を用いた等方的な定量評価．日 放技学誌 2015; 71(12): 1165-1173.

28）北口茂聖，今井國治，上田傑，他．極值統計を用いた CT 画像における金属アーチファクトの定量評価. 日放 技学誌 2016; 72(5): 402-409.

29) Ichikawa K. CTmeasure. Japanese society of CT technology, Kasumi, Minami-ku, Hiroshima, JPN, http: //www.jscttech.org/, 2012-2014.

30) Rasband WS. Image J, U.S. National Institutes of Health, Bethesda, Maryland, USA, http://rsb.info.nih.gov/ij/, 19972012.

31）市川勝弘，小寺吉衞，大橋一也，他，等解像度画像を用い たCT の性能評価。日放技学誌 2006; 62(4): 522-528. 